\title{
Introducing Efficient Low Cost Smoked Pots for Water Purification for Developing Countries
}

\author{
Dong Hun Chung ${ }^{1}$, Josphert N Kimatu ${ }^{2 *}$, Kelvin O Nyariki ${ }^{2}$, Kim Jong $\mathrm{Su}^{2}$, Karren N Onura ${ }^{3}$ and Johnson U Kitheka ${ }^{4}$
}

${ }^{1}$ Ceramics Arts Department, Won Kwang University in South Korea

${ }^{2}$ South Eastern Kenya University, Department of Biological Sciences, Kitui, Kenya

${ }^{3}$ South Eastern Kenya University, Department of Fisheries Management and Aquaculture Technology, Kitui, Kenya

${ }^{4}$ South Eastern Kenya University, Department of Hydrology and Water Resources Management, Kitui, Kenya

\begin{abstract}
Ceramic materials are easy to make using most African soils. They have been used for a long time mainly for cooking and water storage. However, in other low income economies these clay ceramic filters have been shown to have the potential of being improved by being embedded with carbonaceous materials for water purification. In this research we have produced efficient physiological and biological gravity operated smoked pots for water purification. We used well calculated volume ratios of black clay, red and sand soils (B:R:S) and soil balls; All these were baked at different smoke infusing kiln temperatures for efficient water purification. We analyzed water purification efficiencies of the pot ceramics and the trickling rates at different conditions. We isolated the best B:R:S to be the 40:40:20. We found significant reductions in turbidity $(99.95 \%)$, salinity $(21.42 \%)$, microbial populations, total dissolved solutes (TDS) $(17.19 \%), \mathrm{pH}(1.39 \%)$ and electrical conductivity (EC) $(16.92 \%)$. These ceramics can be crucial for common or nomadic communities in sub-Saharan rural areas and in times of disaster to guarantee a cheap continued supply of clean potable water for better health amongst the low income earning societies.
\end{abstract}

Keywords: Water pots; Filtrate; Ceramics; Clay; Purification

\section{Introduction}

Recent data show that about 884 million people in the world are still without potable water [1]. This is even more pronounced in the Sub-Saharan Africa where about $34 \%$ of this water-deprived people are currently living. Furthermore, the World Bank predictions of 2003, show that $25 \%$ of Sub-Saharan Africa will not be having access to potable water resources in 2015 [2], hence measures should be taken to provide water in these areas.

The production of ceramic filters has a long history since the days when Henry Doulton who invented the modern form of ceramic candle sanitary water filter in 1827. In 1835, Queen Victoria commissioned him to produce such a device for her personal use. By 1846, Doulton ceramics was widely recognized as a premier manufacturer of an effective device for treating infective water. Recently, many universities in Asia and Africa alongside some NGOs are supporting the expansion of the use of ceramic filters in drinking water development initiatives; most commonly, in the form of clay pot filters. Millions of these porous clay ceramic water filters are in use at numerous locations in Africa, Asia, and South America [3]. The frustrum shaped pot is very common in Africa. Ron Rivera was a key proponent and innovator who recognized the use of the ceramic frustum shaped (pot) filter and helped developing nations to provide cheap high quality potable water and developing it as an income generating activity. However, studies show that several water filtration technologies have been started to resolve potable water scarcity in the world [4]. These include: Chlorination, chemical coagulants, sunlight exposure techniques, filtration techniques such as nano-membrane filtration, reverse osmosis technique, organic additive based ceramic filters [2,5-11]. UNICEF has in Myanmar initiated water purification technology at the household level [12] and has distributed more than 3,000 ceramic water filters to villages and schools. This has made more than $80 \%$ of the households to have about $90 \%$ customer satisfaction in water hygiene [13]. Other studies have shown that the performance of clay ceramic filters show a decrease in the cases of diarrhea by around $45 \%$ in Bolivia [14,5].
In this study we envisioned to make and evaluate the physical and biological efficacy of clay ceramic water filters on purifying water for drinking using porosity differences, carbon impregnation, and possible Iron III electron transfers in red soil and differences in kilns temperatures. We also planned to suggest a funding to distribute the low cost ceramic water filters to local communities and evaluate socioeconomic parameters and people health on using ceramic filters for more than one year. The results we obtained on electrical conductivity, turbidity, salinity, $\mathrm{pH}$, and total dissolved solutes are very encouraging according to WHO standards and the innovation can be used to provide clean water security to low-income communities and consequently cause a reduction of medical bills in developing countries.

\section{Methodology}

The ceramics were made and baked using locally available materials found at the South Eastern Kenya University in the Kitui County and its environs in Kenya. The analysis of the data was done using the SPSS, 16.0 for Windows, $\mathrm{IBM}^{\oplus}, 2007$ [15].

\section{The pot molding technology and kiln constructions}

After, several trials, the final porous clay ceramic pot filters were molded from moistened suspensions containing black clay, red and sand soils in the ratio: 40:40:20, 35:35:30, 30:50:20 ratios by volume to have the most suitable plasticity and porosity for molding into a

*Corresponding author: Josphert N Kimatu, South Eastern Kenya University, Department of Biological Sciences, Kitui, Kenya, Tel: +254734907740; E-mail: Josphert@yahoo.com

Received June 12, 2013; Accepted July 16, 2013; Published July 22, 2013

Citation: Chung DH, Kimatu JN, Nyariki KO, Su KJ, Onura KN, et al. (2013) Introducing Efficient Low Cost Smoked Pots for Water Purification for Developing Countries. Hydrol Current Res 4: 152. doi:10.4172/2157-7587.1000152

Copyright: (c) 2013 Chung DH, et al. This is an open-access article distributed under the terms of the Creative Commons Attribution License, which permits unrestricted use, distribution, and reproduction in any medium, provided the original author and source are credited. 
frustum. This similar kind of mixing of soils has been done by other researchers like by Donachy, 2004). They were then sintered to around $900^{\circ} \mathrm{C}$ so as to introduce numerous pores into the mold serving its filtration capabilities [16-18]. In the experiment we used four different temperatures in different rooms named R1, R2, R3, R4. The temperatures in each room were: $\mathrm{R} 1,950^{\circ} \mathrm{C}, \mathrm{R} 2,900^{\circ} \mathrm{C}, \mathrm{R} 3,850^{\circ} \mathrm{C}$ and $\mathrm{R} 4,800^{\circ} \mathrm{C}$ as shown in Figure 1 . The experimental pots filters had a lower circumference of $54-60 \mathrm{~cm}$ and a height of $20-25 \mathrm{~cm}$. The filter wall had a thickness of $0.5 \mathrm{~cm}$. We included soil balls of baked ceramics to half the containers. We made the flow characteristics of the filter to be modified so as to be of more efficiency than that from the other $\mathrm{C}-\mathrm{S}$ ratios [16]. The structural feasibility studies for ceramic water filter were performed using some the ideas from the works of [3] and [19].

\section{The impregnation of the carbon into the pots}

The kiln design was made so as to use little wood and provide a production of smoke at high temperatures $\left(800-850^{\circ} \mathrm{C}\right)$ at confined spaces so as to infuse carbon into the porous spaces of the soil mixtures of the pots. The higher temperatures $\left(900-950^{\circ} \mathrm{C}\right)$ where the smoke was not present the pots of different soil mixtures were also fired and used in the water purification analysis experiments.

\section{Biological filtration evaluation of the ceramic filters}

Microbial filtration experiments were performed using 10-20 ml cultures of the non-pathogenic Escherichia coli. The number of viable cells in the pre-filtrate and filtrate suspensions were determined by using the appropriate dilution into sterilized purified water and plating onto agar-agar [20]. The colonies were counted after overnight incubation at $37^{\circ} \mathrm{C}$ and used to calculate viable cells $/ \mathrm{ml}$. The presumptive test to determine the most probable number of coliform bacteria (indicators of fecal contamination), the gram negative, non-spore-forming bacilli that ferment lactose with the production of acid and gas is detectable following a 24 hour incubation period at $37^{\circ} \mathrm{C}$. Aliquots of the water to be tested are measured and added to a lactose fermentation broth containing an inverted gas vial. Because these bacteria are capable of using lactose as a carbon source (the other enteric organisms are not), their detection is facilitated by use of this medium. In this experiment the lactose medium was inoculated with $10 \mathrm{ml}, 1 \mathrm{ml}$ and $0.1 \mathrm{ml}$ aliquots of each pot water sample filtrate. The development of gas in any of the tubes is presumptive evidence of the presence of coliform bacteria in the sample. This test also enabled us to obtain an idea of the number of coliform organisms present by means of the most probable number (MPN) test with a 95\% probability that there are between 22 and 170 microorganisms present.

\section{Physical analysis of water through the pots}

The following were evaluated to determine the physical water properties of the incoming water when compared with the outgoing water from the pots: $\mathrm{pH}$ values, which were estimated by the electrometric method; the conductivity of the samples, which was read by conductivity meter. The electrical conductivity (EC) is an indicator of how salt- free, ion-free, or impurity-free the sample is. This means the purer the water the lower the conductivity. Lastly, we measured the turbidity, which was determined by Nephelometric Turbidity Meter expressed in terms of NTU: Salinity and Total Dissolved Solutes (TDS) were determined using a conductivity meter.

\section{Results}

\section{Determining the pots with the most economical trickling rate}

The various combinations of black, red and sand soils (B:R:S) and different kiln temperatures and turbidity were analyzed and the amount of water which trickled analyzed as shown in Table 1. After several evaluations, the smoked pots with the 40:40:20 soil mixture combinations baked at $800-850^{\circ} \mathrm{C}$ were found to be relatively more economical and efficient water purification properties for use in rural settings.

The pots which were sintered at a kiln temperature above $900^{\circ} \mathrm{C}$ were found to have the lowest trickling rate but had surprisingly more efficient purification properties. They also had red colour and were lighter. The pots sintered at $800^{\circ} \mathrm{C}$ where placed near the mouth of the Kiln and were black (Figure 2). It seems they had carbon from the wood of the Kiln which was embedded in them. This enabled them to be better absorbers of some of the water contaminants.

\section{The analysis of the physical and biological properties of the} pot ceramics

The analysis of the physical and biological purification properties of the filtrate from the various pots were done and analyzed. However, the 40:40:20 combination was found to be the most economical and its results for electrical conductivity, the total dissolved solutes, salinity, turbidity, $\mathrm{pH}$, trickling rate and temperature are shown in the Figure 3. The reduction of the total dissolved solutes (TDS) by $17.19 \%$ from a range of an average of $349 \mathrm{mg} / \mathrm{l}$ of pond water to an average of $289 \mathrm{mg} / \mathrm{l}$ of the filtrate; A reduction of electrical conductivity by $16.92 \%$ from an average of 697 to $579 \mu$ s; a reduction of water acidity by $1.39 \%$ from an average of 7.1 to 7.2 ; a reduction of salinity by $21.42 \%$ from an average of $1.4 \%$ to an average of $1.1 \%$ and a reduction of bacterial microbes by $86 \%$ from an average of 150 counts per $\mathrm{ml}$ to an average of 21 counts per $\mathrm{ml}$.

\section{Effects of high kiln temperatures on the pots}

Two ceramics sintered at different temperatures (that is $800^{\circ} \mathrm{C}$ and $900^{\circ} \mathrm{C}$ ) but of the same mixture of black soil, red soil and sand soil (that is 35:35:30) were tested on various parameters. The average results are as shown in the Figure 4 below. The results confirm that the lower kiln temperatures have an impact in enhancing higher purification without reducing the trickling rates of the water. However, for critical

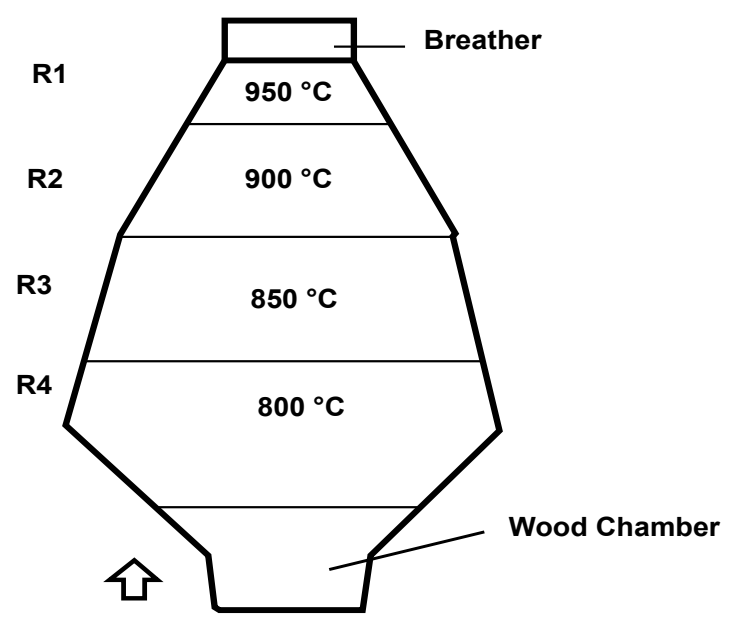

Figure 1: The design of the modified Korean kiln showing the different temperatures rooms (R1, R2, R3 and R4). The arrow on the right shows the direction of the increase in temperature and consequently a gradual decrease in the smoke in the kiln. 
Citation: Chung DH, Kimatu JN, Nyariki KO, Su KJ, Onura KN, et al. (2013) Introducing Efficient Low Cost Smoked Pots for Water Purification for Developing Countries. Hydrol Current Res 4: 152. doi:10.4172/2157-7587.1000152

Page 3 of 5

\begin{tabular}{|c|c|c|c|c|c|c|c|c|c|c|}
\hline & \multirow{2}{*}{ Ingredient } & \multirow{2}{*}{ Room } & \multirow{2}{*}{ Number } & \multirow{2}{*}{ Amount purified $<1 \mathrm{~L} / 30 \mathrm{M}>$} & \multicolumn{6}{|c|}{ Transparency $<$ Good $\rightarrow$ Bad $>$} \\
\hline & & & & & MOST & MORE & BEST & BETTER & BAD & WORST \\
\hline \multirow{5}{*}{ A } & \multirow{5}{*}{$\begin{array}{c}\text { Black : } 40 \\
\text { Red : } 40 \\
\text { Soil : } 20\end{array}$} & \multirow{2}{*}{$\begin{array}{c}\mathrm{R} 2 \\
900^{\circ} \mathrm{C}\end{array}$} & $\mathrm{R} 2-1$ & $100 \mathrm{~m} \ell$ & $\bullet$ & & & & & \\
\hline & & & $\mathrm{R} 2-2$ & $100 \mathrm{~m} \ell$ & & & & $\bullet$ & & \\
\hline & & \multirow{2}{*}{$\begin{array}{c}\mathrm{R} 3 \\
850^{\circ} \mathrm{C}\end{array}$} & R3 - 1 & $545 \mathrm{~m} \ell$ & & & $\bullet$ & & & \\
\hline & & & R3 - 2 & $590 \mathrm{~m} \ell$ & & $\bullet$ & & & & \\
\hline & & $\begin{array}{c}\mathrm{R} 4 \\
800^{\circ} \mathrm{C}\end{array}$ & $\mathrm{R} 4$ & $90 \mathrm{~m} \ell$ & & & & & $\bullet$ & \\
\hline \multirow{6}{*}{ B } & \multirow{6}{*}{$\begin{array}{c}\text { Black : } 35 \\
\text { Red : } 35 \\
\text { Soil : } 30\end{array}$} & \multirow{2}{*}{$\begin{array}{c}\mathrm{R} 2 \\
900^{\circ} \mathrm{C}\end{array}$} & $\mathrm{R} 2-1$ & $10 \mathrm{~m} \ell$ & & $\bullet$ & & & & \\
\hline & & & $\mathrm{R} 2-2$ & $20 \mathrm{~m} \ell$ & & & & & & $\bullet$ \\
\hline & & \multirow{2}{*}{$\begin{array}{c}\mathrm{R} 3 \\
850^{\circ} \mathrm{C}\end{array}$} & $\mathrm{R} 3-1$ & $250 \mathrm{~m} \ell$ & & & & $\bullet$ & & \\
\hline & & & R3 - 2 & $300 \mathrm{ml}$ & & & & & $\bullet$ & \\
\hline & & \multirow{2}{*}{$\begin{array}{c}\mathrm{R} 4 \\
800^{\circ} \mathrm{C}\end{array}$} & $\mathrm{R} 4-1$ & $350 \mathrm{m \ell}$ & & & $\bullet$ & & & \\
\hline & & & $\mathrm{R} 4-2$ & $45 \mathrm{~m} \ell$ & $\bullet$ & & & & & \\
\hline \multirow{6}{*}{ C } & \multirow{6}{*}{$\begin{array}{c}\text { Black : } 30 \\
\text { Red : } 50 \\
\text { Soil : } 20\end{array}$} & \multirow{2}{*}{$\begin{array}{c}\mathrm{R} 1 \\
950^{\circ} \mathrm{C}\end{array}$} & $\mathrm{R} 1-1$ & $1 \mathrm{~m} \ell$ & & & & & & $\bullet$ \\
\hline & & & $\mathrm{R} 1-2$ & $1 \mathrm{~m} \ell$ & & & & & & $\bullet$ \\
\hline & & \multirow{2}{*}{$\begin{array}{c}\mathrm{R} 2 \\
900^{\circ} \mathrm{C}\end{array}$} & $\mathrm{R} 2-1$ & $2 \mathrm{~m} \ell$ & & & $\bullet$ & & & \\
\hline & & & $\mathrm{R} 2-2$ & $90 \mathrm{~m} \ell$ & & $\bullet$ & & & & \\
\hline & & \multirow{2}{*}{$\begin{array}{c}\mathrm{R} 4 \\
800^{\circ} \mathrm{C}\end{array}$} & $\mathrm{R} 4-1$ & $300 \mathrm{~m} \ell$ & & & & & $\bullet$ & \\
\hline & & & $\mathrm{R} 4$ - 2 & $300 \mathrm{~m} \ell$ & & & & $\bullet$ & & \\
\hline
\end{tabular}

Table 1: The trickling rate and the turbidity estimates of the specific ceramic.

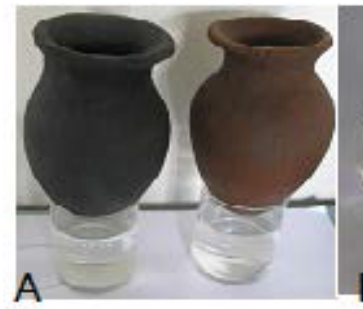

(i) (ii)

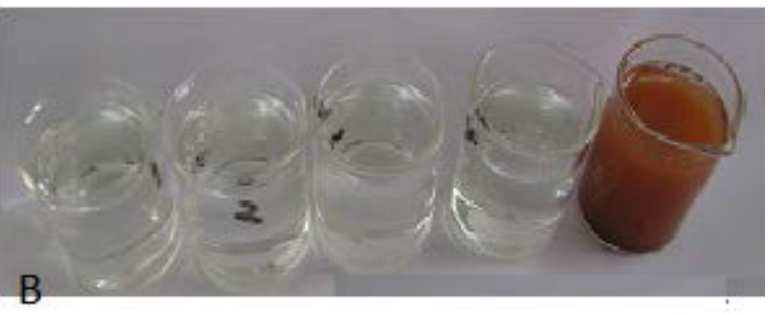

(a) (b) (d)

(e)

Figure 2: A: Example of two ceramics (i) and (ii) which were sintered at a temperature of $800^{\circ} \mathrm{C}$ and $900^{\circ} \mathrm{C}$, respectively. B: Comparisons of pond water (e) with its various filtrates (a), (b), (c) and (d) from the pots of the soil compositions of 30:30:20 (red), 35:35:30 (red), 35:35:30 (black), 40:20:20 (black) respectively.

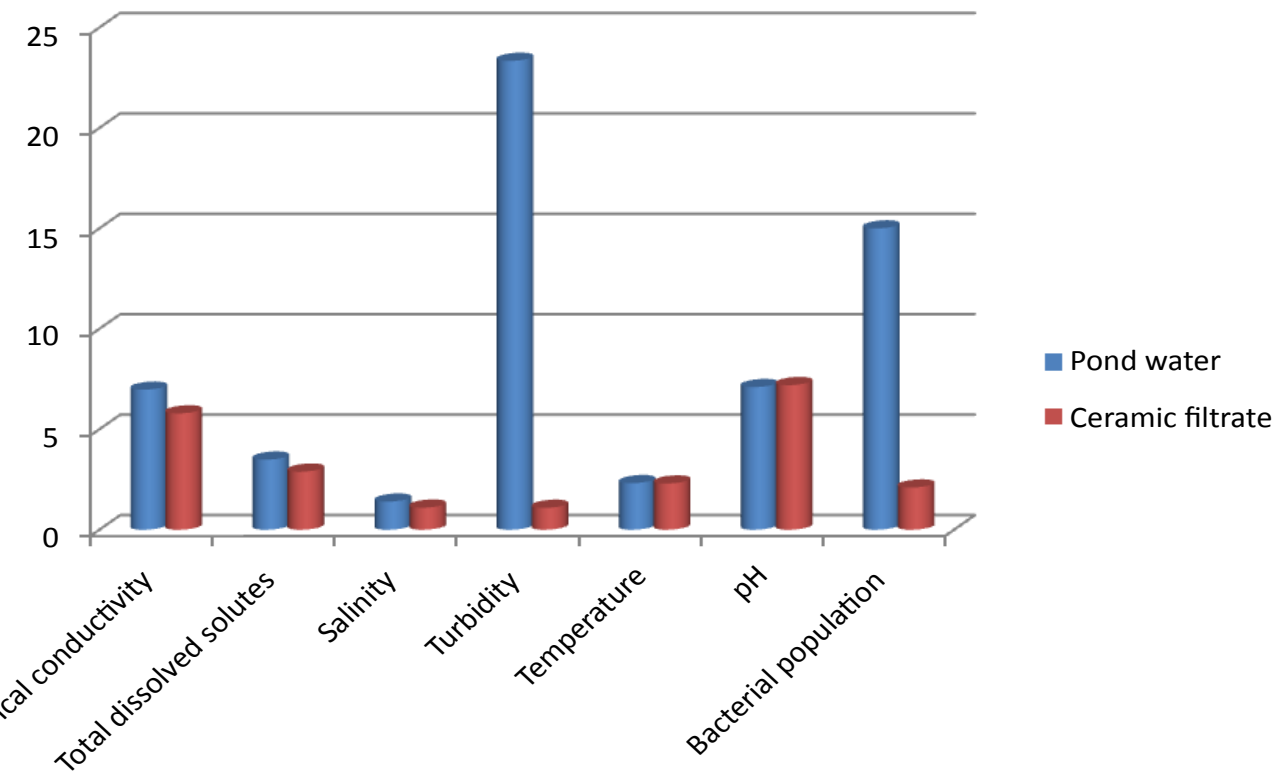

Figure 3: Analysis of the physical parameters of the black clay, red soil and sand (40:40:20) combination, showing reductions in all the parameters. Note: The turbidity of the ceramic filtrate has been multiplied by 100 in the graph for proportionality sake. 
purification of small amounts of water, the higher sintering was isolated as the most preferable.

\section{Analysis of excess salinity in water}

Excess sodium chloride $(\mathrm{NaCl})$ was added to the pond water and was allowed to pass through the various pots. The results were as shown in Figure 5 below. The results showed that the pots sintered at lower kiln temperatures had a lower reduction compared to those which were sintered at higher temperatures. However, the rate of trickling was higher in the black pots. This confirmed the results in the pond water without excess $\mathrm{NaCl}$ above.

\section{Discussions}

There is need to supply constant clean water for the majority of people in developing countries especially in Africa [21-23]. In this research an analysis of physical and biological purification properties of ceramics of different temperatures and composition were evaluated. One of the parameter was the total dissolved solutes (TDS); which provides a rough indication of the overall suitability of water for various purposes. For this parameter, the WHO standard for TDS in drinking water is $250 \mathrm{mg} / \mathrm{L}$ hence the ceramics can be efficient in reducing any common drinking water to the WHO acceptable standards [23]. Turbidity, which is the amount of cloudiness in the water, can reduce

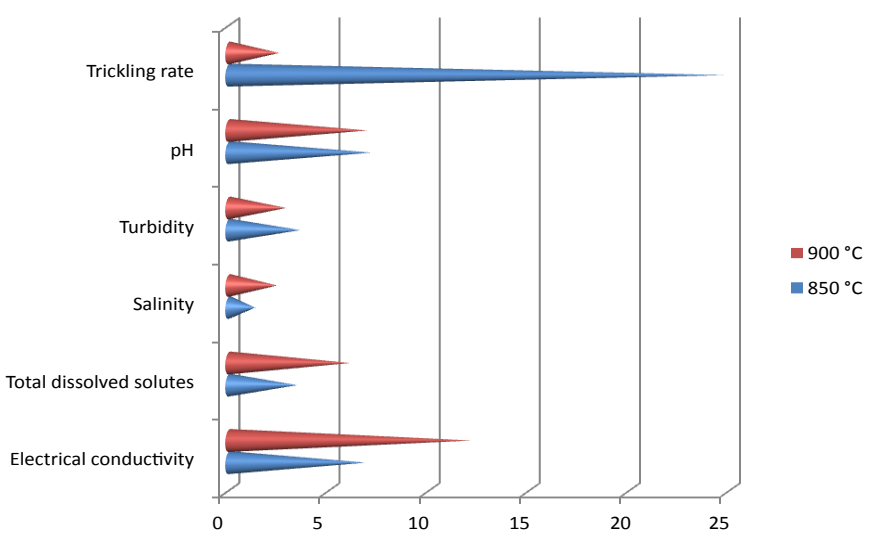

Figure 4: A display of the physical evaluation of results of the 35:35:30 (Black, Red and Sand soils respectively) composition of ceramics which were sintered at different $8500 \mathrm{C}$ and $9000 \mathrm{C}$ temperatures.

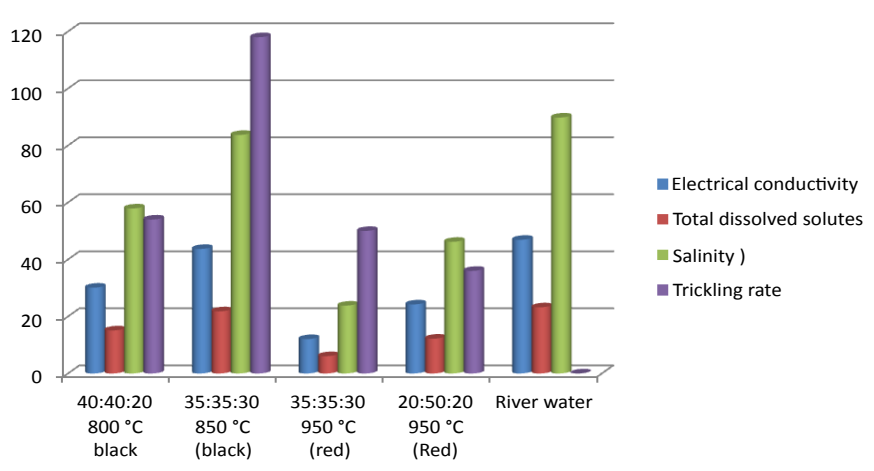

Figure 5: An analysis of salinity reduction from excess $\mathrm{NaCl}$ by various frustums; the higher temperature sintered pots had higher reduction of salinity but lower trickling rate. The 40:40:20 combination ceramics had an economical average of the parameters tested. the aesthetic value of water. In many parts of the sub Saharan region the water turbidity can be caused by organic waste, silt, bacteria and other germs, and chemical precipitates [24]. The ceramics showed a surprising high turbidity reduction of almost $100 \%$.

\section{Modifying and transferring traditional technology for quick adoption}

The design of the kilns was a modified version of the traditional kilns from South Korea which have been used for thousands of years. The kiln used a maximum of $5 \mathrm{mx} 1 \mathrm{mx} 1 \mathrm{~m}$ volume of wood to provide enough heat for the sintering of pots and balls ceramics of approximately $\$ 2000$ worth. We recommend scientifically that a funding of this venture can be a profitable source of employment for locals which is furthermore environmentally friendly and sustainable. However, funding of the project so as to promote mechanized production of the pots ceramics, can increase the quality and efficiency of productivity of the ceramics. It can also increase the supply of pots to a greater number of the rural sub Saharan people who need clean water $[25,26]$. The pots can also be inserted industrially into plastic containers and taps fitted so as to increase its aesthetic value and adoption even among urban populations.

\section{Recommendations}

The above results show that there are other areas of soil chemistry and analysis which we need to do more research on. The use of sintered beads needs further research as there is a possibility that the $\mathrm{Fe}^{3+}$ which involved a transfer of electrons can be instrumental in the generation of infra red photos light beans that could have been the cause of the reductions of microorganisms in the pond water after filtration. The lower temperatures produced smoke (small particles of carbon) which has been known to absorb impurities.

The expansion of the invention can lead to a reduction of waterborne disease burden in Africa; attainment of Millennium Development Goals; provide potable water and improve sanitation to greater number of people in Africa [27]. This can lead to an increase in productivity and in the process, open resources for other socio-economic development and consequently increase income of local rural communities.

\section{Acknowledgement}

The authors gratefully acknowledge Geoffrey Muluvi for His continuous support during the research in South Eastern Kenya University dam site.

\section{References}

1. WHO (2010) Progress on Sanitation and Drinking-water: 2010 Update. WHO Press, World Health Organization, Geneva, Switzerland.

2. Hillie T, Munasinge M, Hlope M, Deraniyagala Y (2009) Nanotechnology, Water and Development, for the commissioned as Part of the Meridian Institute's Global Dialogue on Nanotechnology and the Poor: Opportunities and Risks.

3. Plappally AK, Yakub I, Brown LC, Soboyejo WO, Soboyejo ABO (2009) Theoretical and Experimental Investigation of Water Flow through Porous Ceramic Clay Composite Water Filter. FDMP 5: 373-398.

4. Sobsey MD, Stauber CE, Casanova LM, Brown JM, Elliott MA (2008) Point of Use Household Drinking Water Filtration: A Practical, Effective solution for Providing Sustained Access to Safe Drinking Water in the Developing World Environ Sci Technol 42: 4261-4267.

5. Plappally AK, Yakub I, Brown LC, Soboyejo WO, Soboyejo ABO (2011) Physical Properties of Porous Clay Ceramic-Ware. J Eng Mater Technol 133 09.

6. Clasen T, Nadakatti S, Menon S (2006) Microbiological performance of a water treatment unit designed for household use in developing countries. Trop Med Int Health 11: 1399-1405 
Citation: Chung DH, Kimatu JN, Nyariki KO, Su KJ, Onura KN, et al. (2013) Introducing Efficient Low Cost Smoked Pots for Water Purification for Developing Countries. Hydrol Current Res 4: 152. doi:10.4172/2157-7587.1000152

Page 5 of 5

7. Clasen TF, Brown J, Collin SM (2006) Preventing diarrhoea with household ceramic water filters: assessment of a pilot project in Bolivia. Int $\mathrm{J}$ Environ Health Res 16: 231-239.

8. Clasen T, Schmidt W, Rabie R, Roberts I, Cairncross S (2007) Interventions to improve water quality for preventing diarrhoea: systematic review and metaanalysis. BMJ 334: 782 .

9. Duke WF, Nordin RN, Baker D, Mazumder A (2006) The use and performance of BioSand filters in the Artibonite Valley of Haiti: a field study of 107 households. Rural Remote Health 6: 570.

10. Ngai TK, Shrestha RR, Dangol B, Maharjan M, Murcott SE (2007) Design for sustainable development--household drinking water filter for arsenic and pathogen treatment in Nepal. J Environ Sci Health A Tox Hazard Subst Environ Eng 42: 1879-1888.

11. Plappally A, Soboyejo A, Fausey N, Soboyejo W, Brown L (2010) Stochastic Modeling of Filtrate Alkalinity in Water Filtration Devices: Transport through Micro/Nano Porous Clay Based Ceramic Materials. Journal of Natural and Environmental Sciences 1: 96-105.

12. Plappally AK (2010) Theoretical and Empirical Modeling of Flow, Strength Leaching and Micro-Structural Characteristics of V Shaped Porous Ceramic Water Filters. PhD Dissertation. The Ohio State University, Columbus, $\mathrm{OH}$, USA.

13. UNICEF (2007) UNICEF: World Water Day, commentary, UNICEF Television, Accessed on 07 May 2007.

14. Naing W (2007) Ceramic water filters improve water quality for rural communities in Myanmar Yangon, Myanmar.

15. Lantagne D, Klarman M, Mayer A, Preston A, Napotnik J, (2010) Effect of Production Variables on Microbiological Removal in Locally-produced Ceramic Filters for Household Water Treatment. Int J Environ Health Res 20:171-187.

16. SPSS, 16.0 for Windows, IBM® (2007) Chicago: SPSS Inc
17. Lee C (2001) Investigation into the properties of Filtron. Project at University of Strathclyde, UK

18. Franz A (2005) A performance study on Ceramic Candle filters in Kenya including tests for Coliphage removal. Masters Thesis, MIT Department of Civi and Environmental Engineering. Cambridge, MA, USA

19. Oyanedel-Craver VA, Smith JA (2008) Sustainable colloidal-silver-impregnated ceramic filter for point-of-use water treatment. Environ Sci Technol 42: $927-$ 933.

20. Watters T (2010) The Effect of Compositional and Geometrical Changes to the Bending Strength of the Ghanaian Ceramic Pot Filter. Masters of Engineering Thesis, MIT, Department of Civil and Environmental Engineering, Cambridge MA, USA.

21. Anand Plappally, Haoqian Chen, Wasiu Ayinde, Samson Alayande, Andrew Usoro, et al. (2011) A Field Study on the Use of Clay Ceramic Water Filters and Influences on the General Health in Nigeria. J Health Behav \& Pub Health 1: 1-14.

22. McCarton L (2009) Household Water Management in Sierra Leone, Dublin Institute of Technology.

23. MNN (2010) Maxims New Network: Guinea: Cholera, Water purification and child health (UNICEF), March 19th 2010.

24. Bielefeldt AR, Kowalski K, Summers RS (2009) Bacterial treatment effectiveness of point-of-use ceramic water filters. Water Res 43: 3559-3565.

25. Montgomery MA, Elimelech M (2007) Water and sanitation in developing countries: including health in the equation. Environ Sci Technol 41: 17-24.

26. Clasen T, Naranjo J, Frauchiger D, Gerba C (2009) Laboratory assessment of a gravity-fed ultrafiltration water treatment device designed for household use in low-income settings. Am J Trop Med Hyg 80: 819-823.

27. Olatokun WM, Ayanbode OF (2009) Use of indigenous knowledge by women in a Nigerian rural community. IJTK 8: 287-295. 